\title{
Adaptation to Climate Change in Panchase Mountain Ecological Regions of Nepal
}

\author{
Shankar Adhikari ${ }^{1, *(\mathbb{D})}$, Himlal Baral ${ }^{2,3}$ (1) and Craig Nitschke $^{3 \text { (D) }}$ \\ 1 Department of Forests, Ministry of Forests and Environment, Babarmahal, Kathmandu, Nepal \\ 2 Center for International Forestry Research, Jalan CIFOR, Situ Gede, Sindang Barang, Bogor, \\ Barat 16115, Indonesia; H.Baral@cgiar.org \\ 3 School of Ecosystem and Forest Science, University of Melbourne, Richmond, VIC 3121, Australia; \\ craign@unimelb.edu.au \\ * Correspondence: adhikarishankar@gmail.com; Tel.: +977-9847113360
}

Received: 22 December 2017; Accepted: 8 March 2018; Published: 13 March 2018

\begin{abstract}
Rural mountain communities in developing countries are considered particularly vulnerable to environmental change, including climate change. Forests and agriculture provide numerous ecosystem goods and services (EGS) to local communities and can help people adapt to the impacts of climate change. There is however poor documentation on the role of EGS in people's livelihood and adaptation practices. This study in the rural Panchase Mountain Ecological Region of Nepal identifies practices being used to adapt to a changing environment through key informant interviews and focus group discussions. At the household level, livelihood diversification, changes in cropping patterns and farming practices, use of multipurpose plant species and income-generation activities were identified as adaptation strategies. Among major strategies at the community level were community forestry-based climate adaptation plans of action for forest and water resource management. Landscape-level adaptation strategies were large-scale collaborative projects and programs, such as Ecosystem-based Adaptation and Chitwan Annapurna Landscape conservation; which had implications at both the local and landscape-level. A proper blending and integration of adaptation strategies from individual households through to the community and to the landscape level is needed for implementing effective adaptation in the region.
\end{abstract}

Keywords: adaptation; climate change; community; household; landscape

\section{Introduction}

Rural people, especially in developing parts of the world, are more vulnerable to risks posed by ongoing environmental challenges, including climate change [1-4]. The vulnerability of rural areas within South Asian countries is generally considered through the loss of crops, shelter, community infrastructure, and socio-economic activities [5,6]. This is primarily because people depend on water, food systems, forest products, and other natural resources for their livelihoods. These resources, however, are more vulnerable to the impacts of climate change [7]. As a result, people tend to have limited adaptive capacity to deal with these impacts [3]. The concept of adaptive capacity can be used differently in varying contexts. In the case of adaptation to climate change, we follow the definition by the Intergovernmental Panel on Climate Change (IPCC). It defines adaptive capacity as "the ability of systems, institutions, humans and other organisms to adjust to potential damage, to take advantage of opportunities, or to respond to consequences" [8]. The concept of adaptive capacity is closely related to the vulnerability of socio-ecological systems of communities. Therefore, vulnerability is generally understood as being composed of the exposure and sensitivity of a system to external stresses and the adaptive capacity of the system to adapt to such stresses [9-12]. Moreover, deep-rooted unequal 
social structures and chronic poverty also contribute to the vulnerability of rural communities facing differential climate change impacts [13,14].

Most rural communities in developing nations are endowed with forests, agro-ecosystems, and water resources and the large array of ecosystem goods and services (EGS) they provide. According to the World Bank, 1.6 billion people depend on the EGS derived from forests for their livelihoods [15]. EGS are increasingly recognized for their importance in fostering the adaptive capacity of local communities in response of environmental stressors, such as those posed by climate change, in tandem with socio-economic stresses [16-20]. The practical application of EGS to increase adaptive capacity and human well-being at local level is still debated [21-23]. However, many studies have acknowledged the potential of EGS, especially those providing provisioning and regulating services, to increase adaptive capacity and contribute to human well-being and people's livelihood [24-27].

In Nepal, EGS have a crucial role in supporting the livelihoods of people. Most rural communities in the region depend on forest and farm-based EGS such as fodder, fuel wood, grasses, water, and food for their livelihoods [28-31]. Sixty percent of economically active people are engaged in agriculture as a primary source of livelihood [32]. Forests support agricultural land by providing protection from erosion and landslides, as well as different products such as water resources for irrigation, forage for livestock, and litter for nutrients and organic matter. This makes up the typical relationship between forest, farm, and livestock as an agroforestry practice, especially in the mid-hill region [33]. Traditional energy sources such as fuel wood from forests and agricultural residues and livestock dung still constitute $87 \%$ of the country's total energy supply [34]. Together, forest and agriculture contribute more than one-third of national gross domestic product (GDP) [35-37]. This economic contribution suggests the country is reliant on EGS, especially those derived from forests and agro-ecosystems. Community-based forest management, especially in the mid-hill regions, have contributed to an increase in EGS [38]. Reforestation, restoration of degraded forests, and reduced deforestation and degradation within these regions are responsible for the increase in EGS [38]. In contrast to the hilly region, several anthropogenic disturbances such as grazing, encroachment, deforestation, illegal logging, unsustainable harvesting of non-timber forest products, and forest fire in the lowlands of the southern plain pose many challenges to the sustainable management and use of forest-based EGS [39-42].

In many parts of the world, environmental stressors such as drought, landslides, floods in conjunction with deforestation, and forest degradation, have already had a negative impact on EGS. For example, Nepal Himalaya has experienced a $1.5{ }^{\circ} \mathrm{C}$ increase in temperature between 1982 and 2006, at an average rate of $0.06^{\circ} \mathrm{C}$ per year [43]. This is well above the global average increase in temperature at $0.02{ }^{\circ} \mathrm{C}$ per year observed between 1975 and 2005 [44]. The rapid change in temperature has had implications for food production, water resources, natural hazard prevention, and overall ecosystem function $[43,45,46]$. Consequently, the Climate Change Risk Atlas 2010 ranks Nepal fourth on the list of countries most vulnerable to climate change [47].

Despite being rich in EGS, the people in most rural areas of Nepal are comparatively more vulnerable to climatic risks than in other countries suggesting that a "paradox of plenty" may exist [48]. The reliance of rural communities in Nepal on EGS that are vulnerable to climate variability and change suggests that adaptation to both observed and future changes in climate is necessary $[1,30]$. Adaptation measures operate at different societal and spatial scales [49]. Adaptation measures also require a holistic and integrated approach to implementing community-managed resource-based activities to enhance local adaptive capacity [50]. Activities related to building infrastructure, institutional and communication networks, supported by government initiatives and international organizations are important for fostering adaptive capacity [50]. The effectiveness of these strategies needs to be evaluated based on different criteria that are relevant at different levels [49]. In this context, managing EGS from both forest- and agro-ecosystems could help people meet their basic needs and tackle problems posed by different drivers, including climate change. Some work has been done to document adaptation practices in other countries such as Bangladesh [51-53] and Vietnam [54]. 
However, in Nepal, few studies have systematically documented adaptation measures being used to combat the impact of climate change. A knowledge gap also exists in the potential of locally available EGS to support climate adaptation initiatives from households through to communities and across landscapes. Adaptation initiatives by individual households reflects household-level adaptation [4], whereas community-level adaptation refers to a community-led process and practices designed to empower people to plan and cope with the impacts of climate change [55]. Landscape-level adaptation aims at a broader landscape comprising a mosaic of agricultural land and other natural habitat [56]. This study fills the knowledge gap by documenting adaptation practices from the household to landscape level through a case study from the Panchase Mountain Ecological Region (PMER) of western Nepal. The PMER is rich in natural and socio-cultural resources but is regarded as vulnerable to climate change, which is expected to have negative impacts on forests, water resources, and agriculture diversity [57]. A recent study showed annual average maximum and minimum temperature increases at the rate of 0.043 and $0.023{ }^{\circ} \mathrm{C}$, respectively; precipitation is decreasing by $11.2 \mathrm{~mm}$ per annum and becoming more erratic in pattern [58]. By documenting adaptation practices, the study seeks to understand how they are being implemented and to provide directions for further adaptation planning.

\section{Materials and Methods}

\subsection{Study Area}

The study was carried out in the Panchase Mountain Ecological Region (PMER) (latitude: $28^{\circ} 8^{\prime} 36^{\prime \prime} \mathrm{N}$ to $28^{\circ} 18^{\prime} 17^{\prime \prime}$ N, longitude: $83^{\circ} 43^{\prime} 69^{\prime \prime}$ E to $83^{\circ} 59^{\prime} 5^{\prime \prime}$ E) of western Nepal (Figure 1). The PMER represents the mountain ecosystem linking the lowlands and the high Himalayas of the Annapurna range of Himalaya. Five villages, i.e., Bhadaure Tamagi, Chapakot, Pumdighumdi, Kaskikot, and Dhikurpokhari, were used for the study purpose within this PMER. Out of five villages, Bhadaure Tamagi is the one principally used for data collection. Bhadaure Tamagi typically represents both upstream and downstream regions with distinct land use and farming practices. At the same time, it covers the top of the landscape to the valley bottom downstream. The District Forest Office and Panchase Protected Forest Program (PPFP) also suggested that we choose this site primarily for field observation.

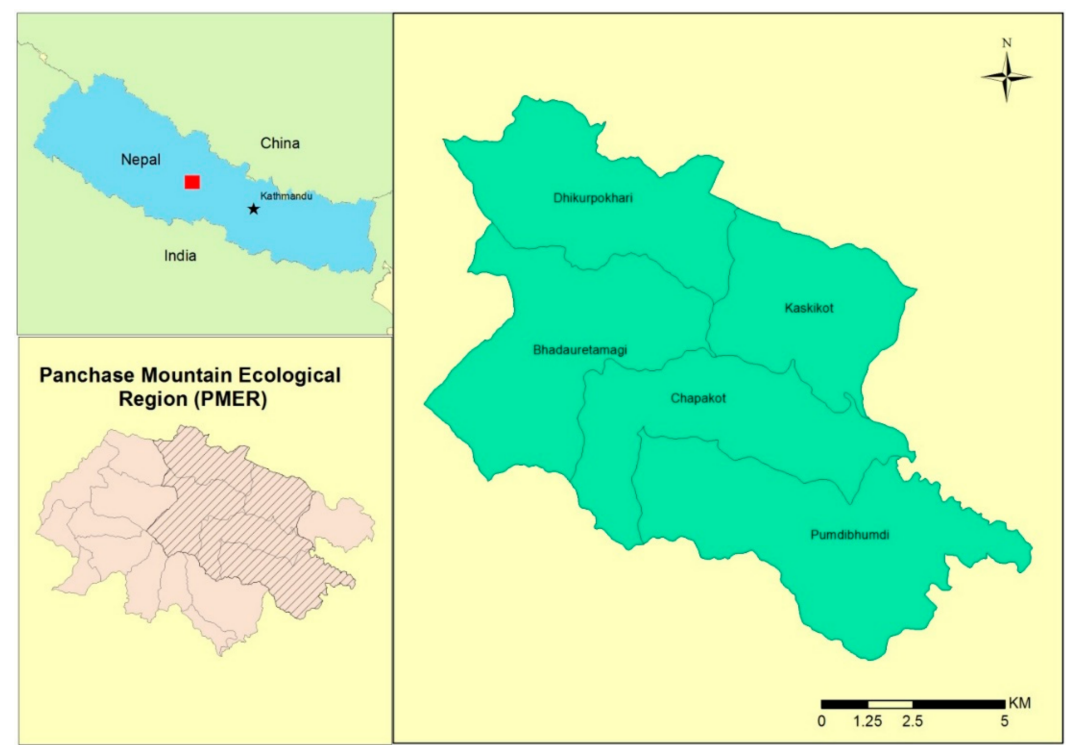

Figure 1. Location map of the Panchase Mountain Ecological Region (PMER) with the chosen study areas within the PMER, Nepal. 
The PMER is rich in forest and biodiversity resources and provides several EGS to the local communities to sustain their livelihoods [59]. More than 14,807 households in the area depend on EGS for their livelihoods. A diversity of goods and services available from the region's forests might be due to the variation in forest and tree species, which occurs across an ecocline of 815 to 2517 meters above sea level [57].

The upstream region (above $1400 \mathrm{~m}$ ) of the study area is dominated by a mix of forest and farmland. The uppermost portion of this region is located within the Panchase protected forest (PPF). The PPF is being managed mainly for conservation of biodiversity, cultural, and religious values, ecosystem services, and medicinal plants. It is also the source of water for both the upstream and downstream regions. Outside the PPF, this region is comprised of farmland and community-managed forest area, which provides both farm- and forest-based goods and services for the livelihoods of local communities.

The downstream region (800-1400 m) for this study is characteristic of a production landscape comprising food and agricultural crops. Downstream $(\sim 800 \mathrm{~m})$ regions encompass flat land in valley bottoms, which is important primarily for production of rice (Oryza spp.), maize (Zea mays), and wheat (Triticum spp.). The fringe area of protected forests and community forests provide basic forest products for communities.

\subsection{Methodological Approach}

In this study, various participatory rural appraisal (PRA) tools were used in data collection [60-64]. The methodological framework is illustrated in Figure 2. Well-facilitated PRAs offer a quick and affordable method for gaining insightful and accurate data $[5,65,66]$. However, the identification of key informants is quite challenging. Even if the right person is chosen, informants might be biased and may not represent, or even understand, views held by the majority in their community [67]. Therefore, it is important to invest time and effort in identifying the appropriate participants for the process. Local community members are good candidates for PRA as they are typically more familiar of the local context than outside experts [68] and are keen to engage in the research process. However, the responses from these participants depend upon how they have interacted with the environment $[65,69]$.

Primary data were collected through various PRA tools such as key informant interviews (KII) [67,70], focus group discussions [51,62,71-73], expert opinion [9,62,74], and direct field observation [58,61]. The PRA tools are particularly important in data-poor developing countries such as Nepal as they do not require a substantial amount of expensive biophysical data [62,75].

First, interviewees for KII were selected based on their knowledge of the local adaptation practices. For example, forest users, current and former executive committee members of community forest user groups (CFUGs); school teachers; members of women's groups, disaster risk reduction (DRR) groups, farmer groups, and indigenous, ethnic, and marginalized groups; and elderly people were identified as key informants [65]. Altogether, 37 in-depth interviews were conducted. Each interview was semi-structured in nature and interviews lasted from 1-1.5 h. The "concept of saturation" was used to determine the number of interviewees [62,76]. This helped keep the sample size small [62,77] while ensuring an optimum level of information as far as possible.

After a series of individual interviews, we organized separate focus group discussions (FGDs) among the villagers and forest managers. First, we appointed a field assistant from the village as a contact point in the field. The field assistant helped identify participants for FGD as per our requirements, contact them before the discussion and then organize FGDs in each locality. The field assistant was from the local community and at the same time had both theoretical and practical knowledge on organizing FGDs, data collection, and group facilitation. These multiple qualifications helped the field assistant identify and organize the FGDs. 


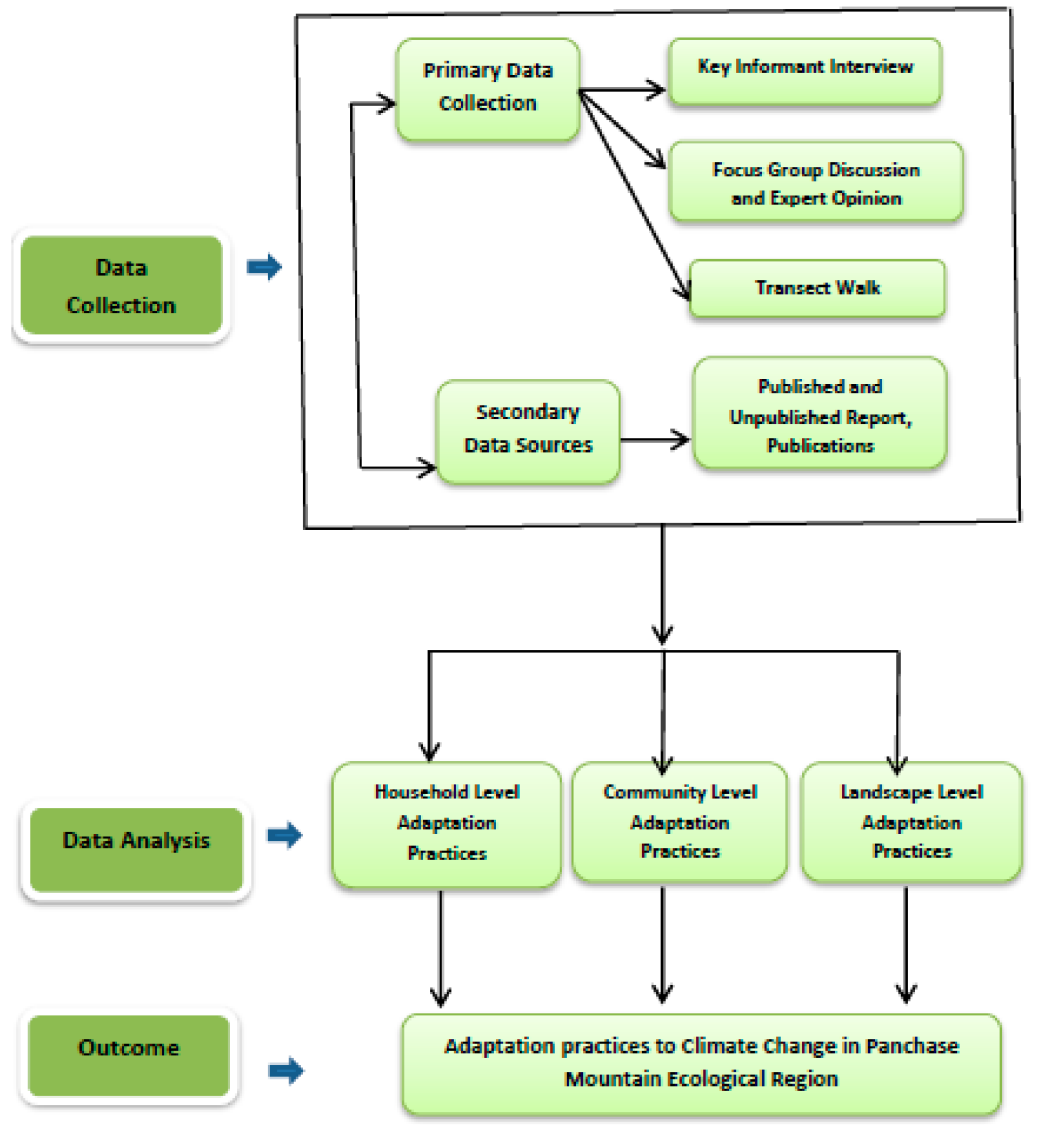

Figure 2. Methodological approach to document household, community and landscape level adaptation practices and associated outcomes in the Panchase Mountain Ecological Region, Nepal.

We held three focus group discussions among villagers and one among forest managers. Each FGD had five participants. As in the KII, participants in the FGD were forest users, executive members of CFUGs, farmers, indigenous and elderly people, and marginalized members of the community. Forest officers, rangers, the manager of PPF, and the chairperson of the PPF Council were involved in FGD and expert opinions at the district headquarters. Some selected participants declined to join the discussion because of conflicting commitments. However, each FGD had at least five members through the participation of alternative participants. The chairpersons of the forest user group and farmers' group were also consulted during the selection of participants for FGDs. As the main purpose of the study was to document the major adaptation practices in the study landscape, we chose participants based on who could contribute more in the discussion and help generate data. Half of the participants were women. We did not organize separate FGDs for male and female participants; the study aimed primarily to identify adaptation measures at the household, community and landscape levels rather than document gender-based disaggregated adaptation practices.

To ensure effective engagement of participants in the discussion (quality) rather than to involve as many participants as possible (quantity) within each FGD, we played the role of facilitator and moderated discussion among participants instead of asking questions repeatedly. As in other PRA tools, FGD can also generate large amounts of data in a relatively short period. Yet, rich data can only be generated if individuals in the group are prepared to engage fully in the process [68]. Public spaces and CF buildings were used for the meeting venue in the community-level FGDs, as well as discussions with participants, whereas the District Forest Office's meeting hall was used for FGDs with forest managers. The main points from the discussion were noted in a diary. The entire discussion was audio recorded and transcribed later for data analysis. 
A transect walk from the lowlands to the peak of the Panchase was conducted to verify information collected through the interviews and FGDs. Published and unpublished reports of relevant government entities and non-governmental organizations (NGOs) were reviewed as secondary sources. These included operational plans of community forests and PPF and community forest-based Climate Adaptation Plans of Action (CAPA). Data were qualitative in nature and analysed in Nvivo [78]. All the interviews were transcribed and translated from Nepali into English prior to analysis using Nvivo.

\section{Results and Discussion}

All the adaptation initiatives in the study landscape are classified into three broad categories: household, community and landscape-level. This was considered the most suitable approach for this study. We acknowledge other studies have recommended different categories such as local, national, and international-level adaptation [49,79]; farm, landscape, and national-level adaptation [80]; and tropical to polar ecosystem-level adaptation [81].

\subsection{Household-Level Adaptation Practices}

Major household-level adaptation practices applied were changing resource-use patterns and gradually shifting livelihoods from existing practices to newer ones more suitable for a changing environment. Changing practices included, for instance, use of biogas instead of firewood, and switching from traditional food crops to multipurpose cash crops and vegetables, income generation, and livelihood diversifications (see Table 1 for details). Household-level adaptation measures related to the use of available EGS derived from forest and agro-ecosystems were some of the most widely applied in the study landscape. This corroborates the findings of earlier studies $[14,30,35,82]$ in Nepal and has also been observed around the world [9,52,53,80,81,83]. For instance, Bhattarai et al. [35] found that, at the household level, cash cropping - especially tomato and adoption of high-yielding improved rice crops-was an adaptation strategy to cope with the environmental impacts on traditional cereal crops. Similar adaptation measures were also observed in Dolakha district, in which kitchen wastewater and rainwater harvesting were used as a household-level adaptation measure [30].

In hazard-prone coastal areas of Bangladesh, important adaptation strategies have also occurred at the household-level such as adoption of new crop varieties, change in planting times, household gardening, rain water harvesting, and tree planting [51,52]. The levels of household adaption identified are consistent with Lopez et al. [80], who defined three measures of household-level adaptation. First, cultivation of a larger number of species and farm diversification; second, introduction of, or increased cultivation of, better-adapted crops and varieties of livestock animals and breeds; and third, integration of trees and shrubs into production systems. 
Table 1. Individual household-level adaptation measures in the study landscape.

\begin{tabular}{|c|c|c|}
\hline Adaptation Practices & Major Activities & Purpose of Adaptation \\
\hline Use of biogas instead of firewood & $\begin{array}{l}\text { - Installment of biogas plant } \\
\text { - Use of cattle dung in biogas }\end{array}$ & $\begin{array}{l}\text { Less pressure on forests for firewood } \\
\text { Clean energy for cooking fin } \\
\text { the kitchs vulnerability to health hazards for women due to reduced level of smoke in }\end{array}$ \\
\hline Efficient water technology (Juthelno sudhar) & - Collection of kitchen water, which otherwise would have gone to waste & $\begin{array}{l}\text { - Efficient use of kitchen water in vegetable farming in the home garden } \\
\text { - Production and use of homegrown organic vegetables }\end{array}$ \\
\hline Livestock-shed improvement (Bhakaro sudhar) & $\begin{array}{l}\text { - Improved management of livestock's dung and urine in which urine is collected } \\
\text { and transferred to the collection spot }\end{array}$ & $\begin{array}{l}\text { - A clean cattle shed with urine collected for organic vegetable farming, which } \\
\text { otherwise would have disappeared or not been used at all }\end{array}$ \\
\hline Use of farmland in cash crops, vegetables and fruit production & $\begin{array}{l}\text { - Conversion of farmland (including abandoned farmland) to grow cash crops } \\
\text { such as vegetables, fruits, coffee and broom grasses in the wake of reduced } \\
\text { productivity of regular cereal crops }\end{array}$ & $\begin{array}{l}\text { - Alternative use of farmland, especially abandoned farmland } \\
\text { Income generation } \\
\text { Product and livelihood diversification } \\
\text { - Reduced invasion of alien and invasive species } \\
\end{array}$ \\
\hline Use of invasive species on organic manure and bio briquette & $\begin{array}{l}\text { - Conversion of invasive weeds into an organic manure } \\
\text { - Use of invasive species as raw materials for bio-briquette }\end{array}$ & $\begin{array}{l}\text { Conversion of invasive weed such as Ageratum conyzoides into organic manure } \\
\text { - Use of available invasive weed species as raw materials for bio-briquette and } \\
\text { bio-energy }\end{array}$ \\
\hline Growing vegetables in polyhouses & $\begin{array}{l}\text { - Taking part in the growing trend of producing vegetables, even off-season } \\
\text { vegetables, in polyhouses }\end{array}$ & $\begin{array}{l}\text { - Support for vegetable requirements in the family and sale of excess products in } \\
\text { the local market } \\
\text { - Employment and income generation }\end{array}$ \\
\hline Livelihood diversification & $\begin{array}{l}\text { Support for livelihood practices in the service sector } \\
\text { comporary and permanent out- migration to the city and even to foreign } \\
\text { countries in search of employment }\end{array}$ & $\begin{array}{l}\text { - Shift of livelihoods from forest and farm-based activities to services sector } \\
\text { - Promotion of ecotourism in the form of homestay business at the local level } \\
\text { Increased family income and livelihood opportunities }\end{array}$ \\
\hline Income generation activities & $\begin{array}{l}\text { - Household-level engagement on income-generating activities such as } \\
\text { beekeeping, vegetable farming and manufacturing of bamboo products, and selling } \\
\text { them at the market }\end{array}$ & - Diversified income source and livelihood opportunities \\
\hline Changing cropping pattern and species & $\begin{array}{l}\text { - Use of more resistant and adaptive varieties of crops such as Bagale Ghaiya and } \\
\text { Chhumlungle Ghaiya rice crops instead of traditional varieties of Resaly Ghaiya } \\
\text { - Different varieties of maize and soybean species } \\
\text { - Changes in cropping time and duration }\end{array}$ & $\begin{array}{l}\text { - Shift of crop varieties and cropping patterns in the wake of contemporary } \\
\text { challenges }\end{array}$ \\
\hline Compost making and farm yard manure improvement & - Preparation and use of compost manure & $\begin{array}{l}\text { - Promotion of organic farming and improved soil health } \\
\text { - Reduced expenses for chemical fertilizers and pesticide }\end{array}$ \\
\hline Fodder and multi-purpose tree plantation, home garden & $\begin{array}{l}\text { - Identification of multipurpose plantations, mainly fodder and fruits tree species, } \\
\text { to meet the local requirement of fodder and fruits } \\
\text { - Plantation and management of tree species on both private and public land. }\end{array}$ & $\begin{array}{l}\text { - Reduced pressure of fodder on forest and strengthened forest conservation } \\
\text { Easy access to fodder resources without spending much time and energy } \\
\text { Enhanced livestock products, and thereby varieties of agro-goods and services } \\
\text { - Promotion of agroforestry practices. }\end{array}$ \\
\hline
\end{tabular}


Various studies have found the limited practice of adaptation options by smallholder farmers due to a limited capacity to implement them $[4,52,84]$. Some identified constraints include lack of money, lack of access to adequate information, inadequate technical knowledge and awareness, and unclear property rights to promote household-level adaptation practices $[4,52,84]$. Individual smallholders should therefore be supported through various adaptation measures such as agroforestry, organic farming, sustainable farm management, low-cost technology, crop diversification, and access to finance and information $[82,85]$. The use of agroforestry practices in particular is a low-cost technology alternative that can increase productivity, generate income, and diversify livelihood opportunities. From an ecological perspective, it will also support ecosystem restoration and soil conservation and reduce land degradation and associated environmental risks.

Household-level adaptation measures were found to be carried out by either individual family members or all family members. Most adaptation practices were autonomous in nature; the household adopts measures on its own in the absence of specific policy initiatives that promote adaptive behavior [86]. Changing species composition and cropping patterns are examples of autonomous adaptation. On the other hand, external agencies may either initiate or support adaptation measures such as promoting vegetable farming in polyhouses through an Ecosystem-based Adaptation (EbA) project. In such cases, adaptation could be understood as "planned" adaptation [81,86]. Similarly, our findings show that if external institutions supported individual autonomous adaptation measures, these measures were more likely to become more effective. The practice of homestay in the study area, supported by EbA projects, was found effective for diversifying livelihoods by generating income not reliant on climate sensitive EGS. Similarly, use of alternative energy such as biogas was also found effective. It exerted less pressure on forests, reduced workloads required to collect firewood, and reduced health hazards by reducing exposure to smoke resulting from traditional cooking stoves. Our study highlights that with the support from government and other external agencies effective adaptation measures at the household level can enhance the adaptive capacity of individual households within communities.

\subsection{Community-Level Adaptation Practices}

We documented some community-level adaptation programs in the study landscape (Table 2). These adaptation practices were found to be initiated by various community-based organizations such as CFUGs, disaster risk reduction groups, farmers' cooperatives, and women's groups in the village. For example, two community forests have an innovative CAPA in water resource management. Community-based restoration and conservation of water ponds were other examples of community-level adaptation to water shortage. Likewise, the role of CFUGs in managing forest fires was also found effective; as a result, forest fire is not a major problem in the region. Further, awareness raising and capacity building of community members, demonstration and conservation plots of threatened plant species were also identified as adaptation measures to cope with the impact of climate change. Due to community engagement in ecosystem management especially via the community forest program, these demonstration and conservation plots also significantly contributed to community-based forest landscape restoration practices. 
Table 2. Community-level adaptation activities in the PMER.

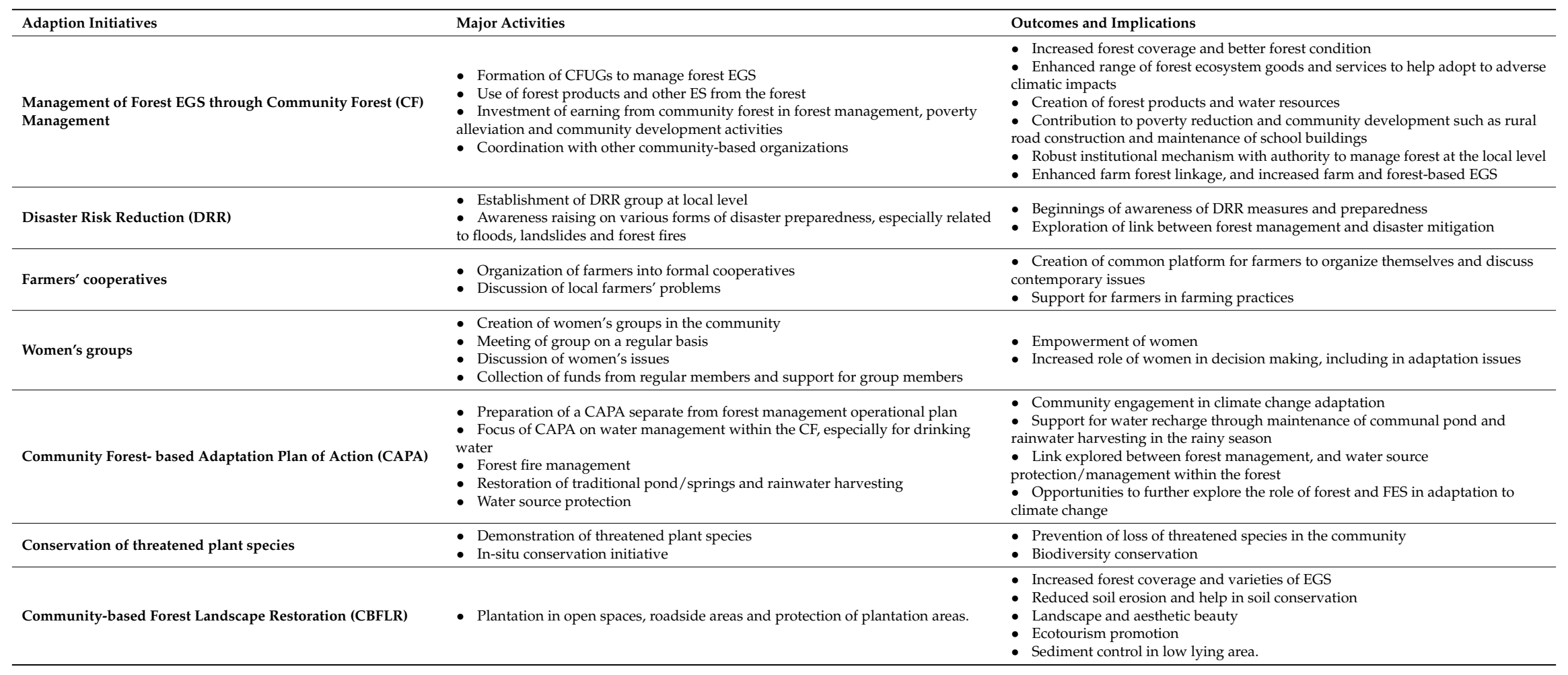


Unlike individual household practices, community-level adaptation initiatives, also known as community-based adaptation (CBA), were based on collective action. The community works for the common benefit to maintain or improve living standards in the face of climate change [87]. CBA should reflect communities' priorities, needs, knowledge, and capacities; it empowers people to plan for and cope with impacts of climate change [45,55]. Even small differences in the pattern of society's fabric for collective action can have profound implications in the ability to cope with environmental shocks, including climate change [88].

Although not designed for adaptation to the impacts of climate change, community forest (CF) management has significantly helped enhance the adaptive capacity of local communities to climate change. Adaptive capacity of local communities has increased due to the formation of natural capital, livelihood (human and social) capital, strong grassroots institutions, and the capacity to manage and use forests within the community [38]. Moreover, CF has also contributed to community-based forest landscape restoration (CBFLR) [89], converting a degraded landscape into one containing rich and diverse areas of forest over the last 30 years $[89,90]$. Similarly, due to increased awareness and engagement on the part of CFUGs, forest fire is no longer a major problem in the landscape. As a result, CF and CBFLR have played a crucial role in biodiversity conservation, ecosystem management, integrated water resource management, improved water quality, and the building of links between forest and agriculture. Ultimately, they have improved the overall livelihoods of people dependent on forest resources $[38,62,89]$. However, even within the same community, vulnerability and adaptive capacity differ from individual to individual and from group to group [91]. Poor and marginalized sections of the communities should be better included in decision making and benefit-sharing mechanisms to increase their adaptive capacity, while directing more benefits toward privileged groups needs to be avoided [92,93].

Following the legacy of successful management of community forestry (CF) in Nepal, CF-based Climate Adaptation Plans of Action (CAPA) have also been initiated in the region. The impact of climatic and environmental stressors has been primarily observed on the availability of water for both drinking and irrigation in the studied landscape. CAPA was designed to protect water sources in the forest and water supply to the village. Other areas incorporated into the CAPA include the conservation and recharge of ponds and managing forest fires in the dry season. A supply of drinking water from the forest, as envisioned in a CF-based CAPA, has helped meet community water requirements in the upstream region but not in the downstream region. This lack of success might be due to pressures from a large population and increased demand of water in downstream areas compared to the upstream region. The growing trend of people migrating from the upstream to downstream regions has put more pressure on natural resources, including forest and water resources downstream [94]. Contrary to the effective community-based fire management practices identified, water management does not appear to be effective at the community level, requiring more robust local institutional and governance mechanisms to support the initiative. Similarly, a disaster risk reduction (DRR) group in the downstream region lacked robust institutional and support mechanisms from within and outside the community. Yet protection and maintenance of community-level conservation ponds in different parts of the region have helped recharge groundwater by collecting excess water in the rainy season and reducing water-induced hazards such as landslides.

The role of community-based institutions in enhancing adaptive capacity and overall effectiveness of adaptation practices has also been acknowledged in other places, especially in disaster risk reduction and climate adaptation [76,90]. For instance, Ahmad et al. [95] prepared the first community-based flood management manuals in South Asia (Bangladesh, India, Nepal) in responses to floods and categorised them into pre-flood responses and responses during floods with a series of steps within each response. As a result, the concept of the community-based flood management committee $[5,95]$ and community-based adaptation committees' (CBACs) [50] has evolved to carry out adaptation activities in the community. In Bangladesh, the local community-level Village Disaster Management Committee (VDMC) that collaborates with local government and other organizations has introduced some 
innovative practices for climate change adaptation [96]. However, maintaining effective coordination among different government and civil society organizations, NGOs, and local communities in the field is still a challenge [96]. In general, decisions for community-level adaptation are based on the autonomous and collective action of community. Any input and support from external organizations could influence the community's decision, and thus its autonomy. Yet, as these practices are based on local and indigenous knowledge, the chance of adaptation success remains high even without input and support from external organizations [97].

\subsection{Landscape-Level Adaptation Initiatives}

Given the considerable socio-ecological importance of Panchase landscapes, various landscape-level conservation and adaptation initiatives have been applied to contemporary environmental challenges. Major initiatives include the Government of Nepal (GoN)-initiated Panchase Protected Forest Program (PPFP), the UNDP-led Ecosystem-based Adaptation-EbA (piloting phase), the IUCN-coordinated Ecosystems Protecting Infrastructure and Communities (EPIC), and the WWF-led Chitwan Annapurna Landscape (CHAL) program in the region. The landscape-level initiatives in the region are another form of adaptation to the impacts of climate change $[98,99]$. The major landscape-level adaptation initiatives in the field are listed in Table 3.

We found that all adaptation initiatives that operate at the landscape level in the region cross beyond traditional political and administrative boundaries. These initiatives were also found to cover a variety of sectors, including protected forests, community forests, ecosystem protection and management, agroforestry, infrastructure protection, and watershed/river basin management. They involved various governmental and non-governmental stakeholders such as IUCN, UNDP, FAO, local NGOs, and communities. The landscape-level initiatives were primarily designed for biodiversity conservation, landscape and scenic beauty, and to provide broader benefits and improve human well-being to both upland and lowland regions through a range of EGS [99]. For example, PPFP was focused on conservation of the biodiversity-rich Panchase forest. The EbA project encouraged both individual households and communities to use EGS to help them adapt to changes throughout the project (ended in 2016).

The major thrust of landscape-level adaptation initiatives was to strengthen the capacity of nature to adapt to the changing climate and then help improve the adaptive capacity of human beings through a variety of EGS [100]. The EbA project has provided a solid framework for planning and implementing integrated adaptation [101]. EbA holds much promise in countries like Nepal that has several landscapes like the PMER with varieties of EGS; at the landscape level, EbA can also help accommodate diverse social, environmental and economic needs during planning and implementation of adaptation activities [101]. However, integrating all those diverse needs and crossing administrative boundaries in climate adaptation activities is still a great challenge that makes decision making complex. Further, much of the development programs and activities take a sectoral approach such as forestry, agriculture, infrastructure and so on. Therefore, breaking the sectoral silos while adopting landscape-level integrated adaptation initiatives should be encouraged for effective landscape-level adaptation in the PMER. 
Table 3. Landscape-level adaptation practices in the PMER.

\begin{tabular}{|c|c|c|}
\hline Adaption Initiatives & Major Activities & Purpose \\
\hline $\begin{array}{l}\text { Government of Nepal (GoN)-initiated Panchase Protected } \\
\text { Forest Program }\end{array}$ & $\begin{array}{l}\text { - Protection of core area of the forest for biodiversity conservation, ES and water } \\
\text { resources } \\
\text { Management of fringe area of protected forests under community forest } \\
\text { management program } \\
\text { - Protection of valuable and threatened species }\end{array}$ & $\begin{array}{l}\text { - Biodiversity conservation and ES } \\
\text { - Water source protection for both upstream and downstream region } \\
\text { - Conmanagement for forest products from the fringe area } \\
\text { - Contion to biodiversity conservation }\end{array}$ \\
\hline $\begin{array}{l}\text { Ecosystem-based Adaptation-EbA Project (piloting phase } \\
\text { 2012-2016) (Partners: GoN, UNDP, IUCN) }\end{array}$ & $\begin{array}{l}\text { - Ecosystem restoration through plantation of multipurpose tree and non-timber } \\
\text { forest products } \\
\text { - Water conservation through water source protection and conservation ponds } \\
\text { - Land rehabilitation: gully control and erosion control supported by vegetative } \\
\text { measures such as plantations } \\
\text { - Livelihood diversification } \\
\text { - Support for individual and community adaptation activities }\end{array}$ & $\begin{array}{l}\text { - Restored ecosystem and maintenance of aesthetic and scenic beauty of the } \\
\text { landscape } \\
\text { - Income generation and employment opportunities at local level through } \\
\text { ecotourism } \\
\text { - Soil conservation and disaster prevention } \\
\text { - Water resource management } \\
\text { - Reduction of vulnerabilities of local communities through water-induced } \\
\text { hazards such as landslides } \\
\text { Increased adaptive capacity of local community with the use of ES, while } \\
\text { helping the ecosystem adapt to the changing climate }\end{array}$ \\
\hline $\begin{array}{l}\text { Ecosystems Protecting Infrastructure and Communities (EPIC) } \\
\text { project (Partners: GoN, IUCN) }\end{array}$ & $\begin{array}{l}\text { - Capacity buildup in climate adaptation } \\
\text { - Integrated management of climate change, disaster and environment }\end{array}$ & $\begin{array}{l}\text { - Strengthened capacities to understand vulnerabilities and act using best practices } \\
\text { Promotion of effective policies for integrated approaches to disasters, climate } \\
\text { change and environment management }\end{array}$ \\
\hline $\begin{array}{l}\text { WWF Nepal-led Chitwan Annapurna Landscape } \\
\text { (CHAL) program }\end{array}$ & $\begin{array}{l}\text { - Watershed management activities in different river basins within the landscape } \\
\text { Control of forest fires, human-wildlife conflict, landslides, unsustainable harvest } \\
\text { and encroachment }\end{array}$ & $\begin{array}{l}\text { Integrated river basin approach } \\
\text { Less vulnerability in the landscape so it can promote species and ecosystem } \\
\text { conservation, ecological connectivity and improved human well-being }\end{array}$ \\
\hline $\begin{array}{l}\text { FAO- and IUCN-led Enhancing Rural Livelihoods in } \\
\text { Underutilised/abandoned Agricultural Land through } \\
\text { Agroforestry piloting project }\end{array}$ & $\begin{array}{l}\text { Awareness building and stakeholder engagement in exploring the ways to use } \\
\text { abandoned and underused land. }\end{array}$ & $\begin{array}{l}\text { - Pilots explore the best agroforestry options for use of abandoned } \\
\text { agricultural/underused land as effective adaptation measures } \\
\text { - A national action plan is developed for scaling up of using } \\
\text { underused/abandoned agricultural land }\end{array}$ \\
\hline
\end{tabular}




\subsection{Integrated Adaptation Approaches}

The assessment of adaptation practices has provided insights into a range of approaches that are used at household-, community- (CBA) and landscape-levels (EbA) within the PMER. Each approach has its specific focus and emphasis. For instance, household-level adaptation and CBA aim to empower individual households and local communities by helping increase adaptive capacity and reducing vulnerability [102]. Conversely, EbA attempts to harness the management and use of ecosystems through a suite of EGS in the face of climate change [99]. However, it would be erroneous to distinguish between EbA and CBA based on their priority for either ecosystem- or people-centered adaptation [103]. Integration of both approaches provides unique opportunities to embrace activities that are both community- and ecosystem-focused such as EGS in people-centered adaptation [103,104]. Moreover, integrated adaptation approaches should fully appreciate ecological and social complexity. For instance, CBA projects may not incorporate ecological complexity, whereas EbA projects might not appreciate social complexity. For example, an EbA project could fail to understand and consider the unique needs of marginalized social groups and how to engage them meaningfully to achieve intended adaptation benefits [103].

Integration of adaptation practices at different scales can be carried out in several ways. First, adaptation at an individual household and community-level should support overall landscape level adaptation and vice versa. For instance, agroforestry practices at the household-level and plantation management in communal lands can support overall landscape-level ecosystem restoration and enhance EGS. The contributions of an individual's adaptation to climate change in landscape-level adaptation have also been reported in Dutch forests [105]. Second, most adaptation planning and implementation take a sectoral approach such as agriculture, forest, water and energy. Though these measures have brought some positive impacts in their respective sectors, an integrated approach at the landscape-level is needed to cross-traditional administrative boundaries for sustainable and effective adaptation in the field [103]. An integrated, coordinated, and targeted strategy is needed for climate change adaptation. In other words, even if integrated adaptation policies have specific strategies in each sector, sector-wide efforts at the landscape or watershed level should increase synergy among adaptation strategies in different sectors and reduce the negative trade-off as far as possible. For example, a larger number of adaptation activities in an agriculture sector were identified; however, to sustain agricultural adaptations, proper management and adaptation of other sectors such as forest conservation, irrigation, and watershed management are required to prevent loss or damage to agricultural-based activities due to landslides, floods, and changes in water availability.

Due to the scale, urgency, complexity, and uncertainty of how climate change may impact ecosystems and rural livelihoods, integrating adaptation approaches and collaborative partnerships are becoming more important than ever [103]. Given the considerable success of community forestry to arrest land degradation and increase forest landscape restoration (FLR) [89], broader-scale community-initiated integrated adaptation approaches could work within the region. Community forestry could be an entry point for implementing integrated adaptation. Similarly, the community forestry-based climate change adaptation (CF-CCA) framework could be a viable option to spearhead integrated adaptation efforts [106]. To ensure household and community-level adaptation are encompassed into a broader landscape-level framework, it is best that "community-led" or "community-controlled" adaptation in EbA be practiced to foster integrated adaptation across scale [103]. Existing networks of local community forest groups could facilitate this process by lowering transaction costs and scaling-up of lessons learned in applying community-lead processes across large and more diverse areas [103].

\section{Conclusions}

Despite rural communities residing in an EGS-rich landscape in Nepal, they are still considered vulnerable to the impacts of climate change in part due to their perceived lack of adaptive capacity. In this study, we found that at the household-level, livelihood diversification, changes in cropping 
patterns and farming practices, use of multipurpose plant species, and income-generation activities are key adaptation strategies being autonomously employed. At the community level, community forestry-based management and water resource management were found to foster adaptive capacity. At the landscape level, adaptation strategies fostered by collaborative projects and programs such as $\mathrm{EbA}$ and $\mathrm{CHAL}$ conservation were found to link some adaptation strategies from local to landscape level. While efforts to implement adaptation are occurring through ecosystem-based adaptation, a strategic integration of adaptation strategies and practices from the household through the community to the landscape-level is required. The integrated approach of adaptation should go beyond the sectoral and administrative boundaries to ensure proper use of EGS within the landscape. Given the considerable success of participatory approaches in forest management, community-led initiatives such as a community forest-based integrated adaptation approach might be a viable option and entry point to promote adaptation practices in the region.

Acknowledgments: The authors would like to thank the Australia Award of the Department of Foreign Affairs and Trade (DFAT) Australia and the University of Melbourne, Australia, for supporting the work. The study was conducted with ethics approval from the Faculty of Science, Human Ethics Advisory Group, the University of Melbourne (Ethics ID: 1543765). Three anonymous referees are gratefully acknowledged for their highly valuable suggestions.

Author Contributions: Shankar Adhikari wrote the paper with significant contribution by Himlal Baral and Craig Nitschke. Shankar Adhikari identified the research question and designed the study with contribution and guidance from Himlal Baral and Craig Nitschke.

Conflicts of Interest: The authors declare no conflict of interest.

\section{References}

1. Gentle, P.; Maraseni, T.N. Climate change, poverty and livelihoods: Adaptation practices by rural mountain communities in Nepal. Environ. Sci. Policy 2012, 21, 24-34. [CrossRef]

2. Mertz, O.; Halsnæs, K.; Olesen, J.E.; Rasmussen, K. Adaptation to climate change in developing countries. Environ. Manag. 2009, 43, 743-752. [CrossRef] [PubMed]

3. Morton, J.F. The impact of climate change on smallholder and subsistence agriculture. Proc. Natl. Acad. Sci. USA 2007, 104, 19680-19685. [CrossRef] [PubMed]

4. Pandey, R.; Kumar, P.; Archie, K.M.; Gupta, A.K.; Joshi, P.K.; Valente, D.; Petrosillo, I. Climate change adaptation in the western-Himalayas: Household level perspectives on impacts and barriers. Ecol. Indic. 2018, 84, 27-37. [CrossRef]

5. Younus, M.A.F. Vulnerability and Adaptation to Climate Change in Bangladesh: Processes, Assessment and Effects; Springer: New York, NY, USA, 2014.

6. Younus, M.A.F. An assessment of vulnerability and adaptation to cyclones through impact assessment guidelines: A bottom-up case study from Bangladesh coast. Nat. Hazards 2017, 89, 1437-1459. [CrossRef]

7. Adger, W.N.; Huq, S.; Brown, K.; Conway, D.; Hulme, M. Adaptation to climate change in the developing world. Prog. Dev. Stud. 2003, 3, 179-195. [CrossRef]

8. Intergovernmental Panel on Climate Change (IPCC). Climate Change 2014-Impacts, Adaptation and Vulnerability: Regional Aspects; Intergovernmental Panel on Climate Change, Cambridge University Press: Cambridge, UK, 2014.

9. Abdul-Razak, M.; Kruse, S. The adaptive capacity of smallholder farmers to climate change in the northern region of Ghana. Clim. Risk Manag. 2017, 17, 104-122. [CrossRef]

10. Adger, W.N. Vulnerability. Glob. Environ. Chang. 2006, 16, 268-281. [CrossRef]

11. Smit, B.; Wandel, J. Adaptation, adaptive capacity and vulnerability. Glob. Environ. Chang. 2006, 16, $282-292$. [CrossRef]

12. Gallopín, G.C. Linkages between vulnerability, resilience, and adaptive capacity. Glob. Environ. Chang. 2006, 16, 293-303. [CrossRef]

13. Agrawal, A. Local institutions and adaptation to climate change. In Social Dimensions of Climate Change: Equity and Vulnerability in a Warming World; World Bank Publications: Washington, DC, USA, 2010; pp. 173-198.

14. Ghimire, Y.N.; Shivakoti, G.P.; Perret, S.R. Household-level vulnerability to drought in hill agriculture of Nepal: Implications for adaptation planning. Int. J. Sustain. Dev. World Ecol. 2010, 17, 225-230. [CrossRef]

15. Chao, S. Forest Peoples: Numbers Across the World; Forest Peoples Programme: Moreton-in-Marsh, UK, 2012. 
16. Butler, C.D.; Oluoch-Kosura, W. Linking future ecosystem services and future human well-being. Ecol. Soc. 2006, 11, 1. [CrossRef]

17. Costanza, R.; d'Arge, R.; De Groot, R.; Farber, S.; Grasso, M.; Hannon, B.; Limburg, K.; Naeem, S.; O'neill, R.V.; Paruelo, J. The value of the world's ecosystem services and natural capital. Ecol. Econ. 1998, 25, 3-15. [CrossRef]

18. Goldman, R.L. Ecosystem services: How people benefit from nature. Environment 2010, 52, 15-23. [CrossRef]

19. Harrison, P.A.; Vandewalle, M.; Sykes, M.T.; Berry, P.M.; Bugter, R.; de Bello, F.; Feld, C.K.; Grandin, U.; Harrington, R.; Haslett, J.R. Identifying and prioritising services in European terrestrial and freshwater ecosystems. Biodivers. Conserv. 2010, 19, 2791-2821. [CrossRef]

20. Nicholson, E.; Mace, G.M.; Armsworth, P.R.; Atkinson, G.; Buckle, S.; Clements, T.; Ewers, R.M.; Fa, J.E.; Gardner, T.A.; Gibbons, J. Priority research areas for ecosystem services in a changing world. J. Appl. Ecol. 2009, 46, 1139-1144. [CrossRef]

21. Boyd, J.; Banzhaf, S. What are ecosystem services? The need for standardized environmental accounting units. Ecol. Econ. 2007, 63, 616-626. [CrossRef]

22. Carpenter, S.R.; Mooney, H.A.; Agard, J.; Capistrano, D.; DeFries, R.S.; Díaz, S.; Dietz, T.; Duraiappah, A.K.; Oteng-Yeboah, A.; Pereira, H.M. Science for managing ecosystem services: Beyond the Millennium Ecosystem Assessment. Proc. Natl. Acad. Sci. USA 2009, 106, 1305-1312. [CrossRef] [PubMed]

23. De Groot, R.S.; Alkemade, R.; Braat, L.; Hein, L.; Willemen, L. Challenges in integrating the concept of ecosystem services and values in landscape planning, management and decision making. Ecol. Complex. 2010, 7, 260-272. [CrossRef]

24. Berbés-Blázquez, M. A participatory assessment of ecosystem services and human well-being in rural Costa Rica using photo-voice. Environ. Manag. 2012, 49, 862-875. [CrossRef] [PubMed]

25. Haines-Young, R.; Potschin, M. The links between biodiversity, ecosystem services and human well-being. In Ecosystem Ecology: A New Synthesis; Cambridge University Press: Cambridge, UK, 2010; pp. 110-139.

26. Howe, C.; Suich, H.; Vira, B.; Mace, G.M. Creating win-wins from trade-offs? Ecosystem services for human well-being: A meta-analysis of ecosystem service trade-offs and synergies in the real world. Glob. Environ. Chang. 2014, 28, 263-275. [CrossRef]

27. Wu, J. Landscape sustainability science: Ecosystem services and human well-being in changing landscapes. Landsc. Ecol. 2013, 28, 999-1023. [CrossRef]

28. Adhikari, B.; Di Falco, S.; Lovett, J.C. Household characteristics and forest dependency: Evidence from common property forest management in Nepal. Ecol. Econ. 2004, 48, 245-257. [CrossRef]

29. Adhikari, M.; Nagata, S.; Adhikari, M. Rural household and forest: An evaluation of household's dependency on community forest in Nepal. J. For. Res. 2004, 9, 3-44. [CrossRef]

30. Bhatta, L.D.; van Oort, B.E.H.; Stork, N.E.; Baral, H. Ecosystem services and livelihoods in a changing climate: Understanding local adaptations in the Upper Koshi, Nepal. Int. J. Biodivers. Sci. Ecosyst. Serv. Manag. 2015, 11, 145-155. [CrossRef]

31. Panta, M.; Kim, K.; Lee, C. Household's characteristics, forest resource dependency and forest availability in Central Terai of Nepal. J. Korean For. Soc. 2009, 98, 548-557.

32. Satyal, V.R. Agriculture in decline. Econ. J. Dev. Issues 2012, 11, 144-157. [CrossRef]

33. Neupane, R.P.; Thapa, G.B. Impact of agroforestry intervention on soil fertility and farm income under the subsistence farming system of the middle hills, Nepal. Agric. Ecosyst. Environ. 2001, 84, 157-167. [CrossRef]

34. Water and Energy Commission Secretariat (WECS). Energy Sector Synopsis Report; Government of Nepal, Water and Energy Commission Secretariat: Kathmandu, Nepal, 2010.

35. Bhattarai, B.; Beilin, R.; Ford, R. Gender, Agrobiodiversity and climate change: A study of adaptation practices in the Nepal Himalayas. World Dev. 2015, 70, 122-132. [CrossRef]

36. Institute for Integrated Development Studies (IIDS). Nepal Economic Outlook 2013/14, Summary Report; Institute for Integrated Development Studies: Kathmandu, Nepal, 2014.

37. Ministry of Finance. Economic Survey, Fiscal Year 2014/15; Government of Nepal, Ministry of Finance: Kathmandu, Nepal, 2015.

38. Niraula, R.R.; Pokharel, B.K. Community forest management as climate change adaptation measure in Nepal's Himalaya. In Climate Change Adaptation Strategies-An Upstream-Downstream Perspective; Springer International Publishing: New York, NY, USA, 2016; pp. 101-120.

39. Panta, M.; Kim, K.; Joshi, C. Temporal mapping of deforestation and forest degradation in Nepal: Applications to forest conservation. For. Ecol. Manag. 2008, 256, 1587-1595. [CrossRef] 
40. Department of Forest Research and Survey (DFRS). State of Nepal's Forests; Forest Resource Assessment (FRA) Nepal, Department of Forest Research and Survey (DFRS): Kathmandu, Nepal, 2015.

41. Department of Forest Research and Survey (DFRS). Terai Forests of Nepal; Forest Resource Assessment (FRA) Nepal, Department of Forest Research and Survey (DFRS): Kathmandu, Nepal, 2014.

42. GoN/MoFSC. Understanding Drivers and Causes of Deforestation and Forest Degradation in Nepal: Potential Policies and Measures for REDD+; Government of Nepal, Ministry of Forests and Soil Conservation, REDD Forestry and Climate Change Cell: Kathmandu, Nepal, 2014.

43. Shrestha, U.B.; Gautam, S.; Bawa, K.S. Widespread climate change in the Himalayas and associated changes in local ecosystems. PLoS ONE 2012, 7, e36741. [CrossRef] [PubMed]

44. Hansen, J.; Sato, M.; Ruedy, R.; Lo, K.; Lea, D.W.; Medina-Elizade, M. Global temperature change. Proc. Natl. Acad. Sci. USA 2006, 103, 14288-14293. [CrossRef] [PubMed]

45. Beniston, M. Climatic change in mountain regions: A review of possible impacts. In Climate Variability and Change in High Elevation Regions: Past, Present E Future; Springer: New York, NY, USA, 2003; pp. 5-31.

46. Jianchu, X.; Shrestha, A.; Vaidya, R.; Eriksson, M.; Hewitt, K. The Melting Himalayas: Regional Challenges and Local Impacts of Climate Change on Mountain Ecosystems and Livelihoods; International Centre for Integrated Mountain Development (ICIMOD): Patan, Nepal, 2007.

47. Regmi, B.; Bhandari, D. Climate change governance and funding dilemma in Nepal. TMC Acad. J. 2012, 7, 40-55.

48. Douglas, L.R.; Alie, K. High-value natural resources: Linking wildlife conservation to international conflict, insecurity, and development concerns. Biol. Conserv. 2014, 171, 270-277. [CrossRef]

49. Adger, W.N.; Arnell, N.W.; Tompkins, E.L. Successful adaptation to climate change across scales. Glob. Environ. Chang. 2005, 15, 77-86. [CrossRef]

50. Younus, M.A.F. Adapting to climate change in the coastal regions of Bangladesh: Proposal for the formation of community-based adaptation committees. Environ. Hazards 2017, 16, 21-49. [CrossRef]

51. Sultana, Z.; Mallick, B. Adaptation Strategies after Cyclone in Southwest Coastal Bangladesh-Pro Poor Policy Choices. Am. J. Rural Dev. 2015, 3, 24-33. [CrossRef]

52. Alam, G.M.; Alam, K.; Mushtaq, S. Climate change perceptions and local adaptation strategies of hazard-prone rural households in Bangladesh. Clim. Risk Manag. 2017, 17, 52-63. [CrossRef]

53. Kabir, M.J.; Alauddin, M.; Crimp, S. Farm-level adaptation to climate change in Western Bangladesh: An analysis of adaptation dynamics, profitability and risks. Land Use Policy 2017, 64, 212-224. [CrossRef]

54. Nguyen, Q.; Hoang, M.H.; Öborn, I.; van Noordwijk, M. Multipurpose agroforestry as a climate change resiliency option for farmers: An example of local adaptation in Vietnam. Clim. Chang. 2013, 117, $241-257$. [CrossRef]

55. Reid, H.; Alam, M.; Berger, R.; Cannon, T.; Milligan, A. Community-Based Adaptation to Climate Change, Participatory Learning and Action; International Institute for Environment and Development: London, UK, 2009.

56. Vignola, R.; Harvey, C.A.; Bautista-Solis, P.; Avelino, J.; Rapidel, B.; Donatti, C.; Martinez, R. Ecosystem-based adaptation for smallholder farmers: Definitions, opportunities and constraints. Agric. Ecosyst. Environ. 2015, 211, 126-132. [CrossRef]

57. Baral, S.; Adhikari, A.; Khanal, R. Forests Resources Conservation: Building Resilience of Forest Ecosystem in the Panchase Area; IUCN Nepal: Lalitpur, Nepal, 2014.

58. Heyojoo, B.P.; Yadav, N.K.; Subedi, R. Assessments of Climate Change Indicators, Climate-Induced Disasters, and Community Adaptation Strategies: A Case from High Mountain of Nepal. In Land Cover Change and Its Eco-Environmental Responses in Nepal; Springer: Singapore, 2017; pp. 203-221.

59. International Union for Conservation of Nature and Natural Resources (IUCN). Scoping of Piloting Ecosystem Based Adaptation in Panchase' A Report; IUCN: Kathmandu, Nepal, 2012.

60. Chambers, R. Participatory rural appraisal (PRA): Analysis of experience. World Dev. 1994, 22, $1253-1268$. [CrossRef]

61. Chambers, R. Participatory rural appraisal (PRA): Challenges, potentials and paradigm. World Dev. 1994, 22, 1437-1454. [CrossRef]

62. Paudyal, K.; Baral, H.; Putzel, L.; Bhandari, S.; Keenan, R.J. Change in land use and ecosystem services delivery from community-based forest landscape restoration in the Phewa Lake watershed, Nepal. Int. For. Rev. 2017, 19, 1-14. [CrossRef] 
63. Younus, M.A.F.; Sharna, S.S. Combination of community-based vulnerability and adaptation to storm surges in coastal regions of Bangladesh. J. Environ. Assess. Policy Manag. 2014, 16, 1450036. [CrossRef]

64. Baral, H.; Jaung, W.; Bhatta, L.D.; Phuntsho, S.; Sharma, S.; Paudyal, K.; Zarandian, A.; Sears, R.; Sharma, R.; Dorji, T.; et al. Approaches and Tools for Assessing Mountain Forest Ecosystem Services; Working Paper 235; Center for International Forestry Research (CIFOR): Bogor, Indonesia, 2017.

65. Paudyal, K.; Baral, H.; Burkhard, B.; Bhandari, S.P.; Keenan, R.J. Participatory assessment and mapping of ecosystem services in a data-poor region: Case study of community-managed forests in central Nepal. Ecosyst. Serv. 2015, 13, 81-92. [CrossRef]

66. Younus, M.A.F.; Harvey, N. Community-based flood vulnerability and adaptation assessment: A case study from Bangladesh. J. Environ. Assess. Policy Manag. 2013, 15, 1350010. [CrossRef]

67. Marshall, M.N. The key informant technique. Fam. Pract. 1996, 13, 92-97. [CrossRef] [PubMed]

68. Nightingale, A.J. "The experts taught us all we know": Professionalisation and knowledge in Nepalese community forestry. Antipode 2005, 37, 581-604. [CrossRef]

69. Garrard, R.; Kohler, T.; Wiesmann, U.M.; Price, M.F.; Byers, A.C.; Sherpa, A.R. Depicting community perspectives: Repeat photography and participatory research as tools for assessing environmental services in Sagarmatha National Park, Nepal. Eco.mont J. Prot. Mount. Areas Res. 2012, 4, 21-31. [CrossRef]

70. Bryman, A. Social Research Methods; Oxford University Press: Oxford, UK, 2015.

71. Gray, D.E. Doing Research in the Real World; Sage: Newcastle upon Tyne, UK, 2013.

72. Rabiee, F. Focus-group interview and data analysis. Proc. Nutr. Soc. 2004, 63, 655-660. [CrossRef] [PubMed]

73. Regmi, B.R.; Star, C.; Leal Filho, W. An overview of the opportunities and challenges of promoting climate change adaptation at the local level: A case study from a community adaptation planning in Nepal. Clim. Chang. 2016, 138, 537-550. [CrossRef]

74. Burkhard, B.; Kroll, F.; Nedkov, S.; Müller, F. Mapping ecosystem service supply, demand and budgets. Ecol. Indic. 2012, 21, 17-29. [CrossRef]

75. Baral, H.; Keenan, R.J.; Stork, N.E.; Kasel, S. Measuring and managing ecosystem goods and services in changing landscapes: A south-east Australian perspective. J. Environ. Plan. Manag. 2014, 57, 961-983. [CrossRef]

76. Glaser, B.G.; Strauss, A.L. The Discovery of Grounded Theory: Strategies for Qualitative Research; Aldine: Piscataway, NJ, USA, 1967.

77. Malterud, K.; Siersma, V.D.; Guassora, A.D. Sample size in qualitative interview studies: Guided by information power. Qual. Health Res. 2016, 26, 1753-1760. [CrossRef] [PubMed]

78. Azeem, M.; Salfi, N.A.; Dogar, A. Usage of NVivo software for qualitative data analysis. Acad. Res. Int. 2012, 2, 262-266.

79. Adger, W.N. Scales of governance and environmental justice for adaptation and mitigation of climate change. J. Int. Dev. 2001, 13, 921-931. [CrossRef]

80. López Noriega, I.; Dawson, I.K.; Vernooy, R.; Köhler-Rollefson, I.; Halewood, M. Agricultural diversification as an adaptation strategy. Agric. Dev. 2017, 30, 25-28.

81. Huntington, H.; Begossi, A.; Fox Gearheard, S.; Kersey, B.; Loring, P.; Mustonen, T.; Paudel, P.; Silvano, R.; Vave, R. How small communities respond to environmental change: Patterns from tropical to polar ecosystems. Ecol. Soc. 2017, 22, 9.

82. Manandhar, S.; Vogt, D.S.; Perret, S.R.; Kazama, F. Adapting cropping systems to climate change in Nepal: A cross-regional study of farmers' perception and practices. Reg. Environ. Chang. 2011, 11, 335-348. [CrossRef]

83. Cohn, A.S.; Newton, P.; Gil, J.D.; Kuhl, L.; Samberg, L.; Ricciardi, V.; Manly, J.R.; Northrop, S. Smallholder agriculture and climate change. Ann. Rev. Environ. Resour. 2017, 42, 347-375. [CrossRef]

84. Bastakoti, R.C.; Bharati, L.; Bhattarai, U.; Wahid, S.M. Agriculture under changing climate conditions and adaptation options in the Koshi Basin. Clim. Dev. 2017, 9, 634-648. [CrossRef]

85. Biggs, E.M.; Tompkins, E.L.; Allen, J.; Moon, C.; Allen, R. Agricultural adaptation to climate change: Observations from the Mid-Hills of Nepal. Clim. Dev. 2013, 5, 165-173. [CrossRef]

86. Smit, B.; Burton, I.; Klein, R.J.; Street, R. The science of adaptation: A framework for assessment. Mitig. Adapt. Strateg. Glob. Chang. 1999, 4, 199-213. [CrossRef]

87. Van Aalst, M.K.; Cannon, T.; Burton, I. Community level adaptation to climate change: The potential role of participatory community risk assessment. Glob. Environ. Chang. 2008, 18, 165-179. [CrossRef] 
88. Aldrich, D.P. Building Resilience: Social Capital in Post-Disaster Recovery; University of Chicago Press: Chicago, IL, USA, 2012; p. 232.

89. Paudyal, K.; Putzel, L.; Baral, H.; Chaudhary, S.; Sharma, R.; Bhandari, S.; Poudel, I.; Keenan, R.J. From denuded to green mountains: Process and motivating factors of forest landscape restoration in Phewa Lake watershed, Nepal. Int. For. Rev. 2017, 19, 75-87. [CrossRef]

90. Fleming, B.; Fleming, J.P. A watershed conservation success story in Nepal: Land use changes over 30 years. Waterlines 2009, 28, 29-46. [CrossRef]

91. Mallick, B. Necessity of Acceptance-Searching for a Sustainable Community Based Disaster Mitigation Approach. In Proceedings of the 2011 Solutions to Coastal Disasters Conference, Anchorage, AK, USA, 25-29 June 2011; Wallendorf, L., Ed.; ASCE \& COPRI: Reston, VA, USA, 2011; pp. 753-766.

92. Chaudhary, S.; McGregor, A.; Houston, D.; Chettri, N. Environmental justice and ecosystem services: A disaggregated analysis of community access to forest benefits in Nepal. Ecosyst. Serv. 2018, 29, 99-115. [CrossRef]

93. Thomas, D.S.; Twyman, C. Equity and justice in climate change adaptation amongst natural-resource-dependent societies. Glob. Environ. Chang. 2005, 15, 115-124. [CrossRef]

94. Jaquet, S.; Schwilch, G.; Hartung-Hofmann, F.; Adhikari, A.; Sudmeier-Rieux, K.; Shrestha, G.; Liniger, H.P.; Kohler, T. Does outmigration lead to land degradation? Labour shortage and land management in a western Nepal watershed. Appl. Geogr. 2015, 62, 157-170. [CrossRef]

95. Ahmed, A.U.; Zahurul, K.; Prasad, K.; Poudel, S.N.; Sharma, S.K. Synthesis of manuals on community flood management in Bangladesh, India and Nepal. Asia Pac. J. Environ. Dev. 2004, 11, 1-39.

96. Karim, M.R.; Thiel, A. Role of Community Based Local Institution for Climate Change Adaptation through Participatory Approach in Teesta Riverine Area of Bangladesh. Clim. Risk Manag. 2017, 17, 92-103. [CrossRef]

97. Keenan, R. Climate change impacts and adaptation in forest management: A review. Ann. For. Sci. 2015, 72, 145-167. [CrossRef]

98. $\mathrm{Xu}, \mathrm{J} . ;$ Wiley Interdiscip. Rev. Clim. Chang. 2014, 5, 709-718. [CrossRef]

99. Sayer, J.; Sunderland, T.; Ghazoul, J.; Pfund, J.-L.; Sheil, D.; Meijaard, E.; Venter, M.; Boedhihartono, A.K.; Day, M.; Garcia, C. Ten principles for a landscape approach to reconciling agriculture, conservation, and other competing land uses. Proc. Natl. Acad. Sci. USA 2013, 110, 8349-8356. [CrossRef] [PubMed]

100. Vignola, R.; Locatelli, B.; Martinez, C.; Imbach, P. Ecosystem-based adaptation to climate change: What role for policy-makers, society and scientists? Mitig. Adapt. Strateg. Glob. Chang. 2009, 14, 691. [CrossRef]

101. Government of Nepal; Department of Forests; United Nations Development Programme. Project Completion Report of Ecosystem Based Adaptation in Mountain Ecosystems in Nepal Project; Government of Nepal; Department of Forests; United Nations Development Programme: Kathmandu, Nepal, 2016.

102. Ayers, J.; Forsyth, T. Community-based adaptation to climate change. Environ. Sci. Policy Sustain. Dev. 2009, 51, 22-31. [CrossRef]

103. Girot, P.; Ehrhart, C.; Oglethorpe, J.; Reid, H.; Rossing, T.; Gambarelli, G.; Phillips, J. Integrating Community and Ecosystem-Based Approaches in Climate Change Adaptation Responses. Ecosystem and Livelihoods Adaptation Network (ELAN), 2012. Available online: http:/ / www.elanadapt.net/ (accessed on 22 December 2017).

104. Bürgi, M.; Ali, P.; Chowdhury, A.; Heinimann, A.; Hett, C.; Kienast, F.; Mondal, M.K.; Upreti, B.R.; Verburg, P.H. Integrated Landscape Approach: Closing the Gap between Theory and Application. Sustainability 2017, 9, 1371. [CrossRef]

105. Hengeveld, G.M.; Didion, M.; Clerkx, S.; Elkin, C.; Nabuurs, G.J.; Schelhaas, M.J. The landscape-level effect of individual-owner adaptation to climate change in Dutch forests. Reg. Environ. Chang. 2015, 15, 1515-1529. [CrossRef]

106. Chowdhary, C.; Conroy, W.; Gritten, D.; Pairojmahakij, R.; Poudyal, B.; Sapkota, L.; Triraganon, R. Integrated climate change adaptation: Towards an eman-cipatory community forestry-based approach. Int. For. Rev. 2017, 19, 24-40. [CrossRef]

(c) 2018 by the authors. Licensee MDPI, Basel, Switzerland. This article is an open access article distributed under the terms and conditions of the Creative Commons Attribution (CC BY) license (http:/ / creativecommons.org/licenses/by/4.0/). 